\title{
In vitro antifungal activity of Ocimum selloi essential oil and methylchavicol against phytopathogenic fungi ${ }^{1}$
}

\author{
Atividade antifúngica in vitro do óleo essencial de Ocimum selloi e metilchavicol \\ contra fungos fitopatogênicos
}

\author{
Larissa Corrêa Bomfim Costa ${ }^{2}$, José Eduardo Brasil Pereira Pinto ${ }^{3 *}$, Suzan Kelly Vilela Bertolucci ${ }^{4}$, João Cássia \\ do Bomfim Costa ${ }^{5}$, Péricles Barreto Alves ${ }^{6}$ e Edenilson dos Santos Niculau ${ }^{6}$
}

\begin{abstract}
The efficacy of Ocimum selloi essential oil was evaluated for controlling the growth of mycelia and spores germination Moniliophthora perniciosa. Six compounds (99.89\%) of the total oil were identified by GC-MS, of which methyl chavicol, methyl eugenol, $\beta$-caryophyllene, germacrene-D, bicyclogermacrene and spathulenol. Essential oil was tested for antifungal activity, which was determined by disc diffusion and minimum inhibitory concentration (MIC) determination methods. Application of the oil reduced mycelial growth in a dose dependent manner, with maximum inhibition being observed at concentration of $1,000 \mathrm{ppm}$. Such antifungal activity could be attributed to methyl chavicol since the pure compound was shown to be similarly effective against Moniliophthora perniciosa at 1,000 ppm. The oil when applied at a concentration of 1,000 ppm, reduced the spore germination of Colletotrichum gloeosporioides and M. perniciosa by 93 and 87\%, respectively, but had no effect on the Alternaria alternata. It is concluded that the oil from $O$. selloi and its major constituent, methyl chavicol, are efficient in inhibiting M. perniciosa, but less effective against $C$. gloeosporioides and A. alternata. The results obtained from this work may contribute to the development of alternative anti-fungal agents to protect the cacao crop from fungal disease.
\end{abstract}

Key words: Antifungal Activity. Methyl Chavicol. Moniliophthora perniciosa. Theobroma cacao.

RESUMO - A eficácia do óleo essencial de Ocimum selloi na inibição do crescimento micelial e na germinação de esporos foi avaliada in vitro para os fungos Moniliophthora perniciosa, Colletotrichum gloesporioides e Alternaria alternata. Seis constituintes (99,89\%) do total do óleo foram identificados por CG-EM metil chavicol, metil eugenol, $\beta$-cariofileno, germacreno-D, biclogermacreno e espatulenol. O óleo essencial foi testado para atividade antifúngica, o qual foi determinado pelos métodos de difusão e concentração mínima inibitória (MIC). A aplicação do óleo reduziu o crescimento micelial dependente da dose, com máxima inibição na concentração de 1.000 ppm. A atividade antifúngica pode ser atribuída ao composto puro metil chavicol. Este mostrou ser efetivo contra M. perniciosa em 1.000 ppm. O óleo quando aplicado na concentração de $1.000 \mathrm{ppm}$, reduziu a germinação do esporo de Colletotrichum gloeosporioides e M. perniciosa em 93 e 87\%, respectivamente, mas não teve efeito em Alternaria alternata. Conclui-se que o óleo essencial e seu constituinte majoritário, metil chavicol, são eficientes na inibição de $M$. perniciosa, mas menos efetivo contra $C$. gloeosporioides e A. alternata. Os resultados obtidos nesta pesquisa pode contribuir para o desenvolvimento de um agente alternativo para proteger a cultura do cacao contra esta doença fúngica.

Palavras-chave: Atividade Antifúngica. Metil chavicol. Moniliophthora perniciosa, Theobroma cacao.

\footnotetext{
DOI: $10.5935 / 1806-6690.20150023$

*Autor para correspondência

${ }^{1}$ Recebido para publicação em 08/11/2013; aprovado em 16/01/2015

Parte da Tese de Doutorado do primeiro autor apresentada na Universidade Federal de Lavras/UFLA

${ }^{2}$ Departamento de Ciência Biológica/Anatomia e Plantas Medicinais, Universidade Estadual de Santa Cruz, Ilhéus-BA, Brasil, larissa@uesc.br

${ }^{3}$ Departamento de Agricultura/Cultura de Tecidos e Plantas Medicinais, Universidade Federal de Lavras, Av. Doutor Sylvio Menicucci, 1001,

Kennedy, Câmpus Universitário, Caixa Postal 3037, Lavras-MG, Brasil, 37.200-000, jeduardo@dag.ufla.br

${ }^{4}$ Departamento de Agricultura/Fitoquimica e Plantas Medicinais, Universidade Federal de Lavras, Lavras-MG, Brasil, suzan@ dag.ufla.br

${ }^{5}$ Centro de Pesquisas do Cacau, Itabuna-BA, Brasil, jcbcosta@uol.com.br

${ }^{6}$ Departamento de Química, Universidade Federal de Sergipe, São Cristóvão-SE, Brasil, periclesbalves@ gmail.com, edenilsonnicolau@ @otmail.com
} 


\section{INTRODUCTION}

The essential oils of numerous aromatic and medicinal plants are known to possess antimicrobial activity (CAROVIĆ-STANKO et al., 2010). Indeed, a wide range of plant secondary metabolites exhibit antimicrobial properties, and these are often associated with the natural defense mechanism against attack by phytopathogenic bacteria and fungi (JANSSEN; SCHEFFER; BAERHEIM-SVENDSEN, 1987). In this context, a number of studies have shown that crude plant extracts and essential oils are potentially useful for controlling various types of phytopathogens (CARVALHO et al., 2013; RAHMAN; HOSSAIN; KANG, 2010; SILVA et al., 2012a; SILVA et al., 2012b; SILVA; BASTOS 2007; VIGO-SCHULTZ et al., 2006).

Alternaria alternata (Fr.) Keissl., Colletotrichum spp. and Moniliophthora perniciosa (Stahel) Aime \& Phillips-Mora [syn. Crinipellis perniciosa (Stahel) Singer] are representative of phytopathogens that cause significant economic losses both in Brazil and in many other areas of the world. The mould A. alternata is an opportunist pathogen that is responsible for leaf spot and blight disease in more than 380 plant species, while fungi of the genus Colletotrichum cause economically significant diseases (e.g. anthracnose) in cereals, grasses, fruit and ornamental plants, mainly in tropical and subtropical regions (SOUZA JÚNIOR; SALES; MARTINS, 2009). Of particular interest, however, is the hemibiotrophic fungus M. perniciosa, the causal agent of witches' broom disease in Theobroma cacao L. (GRIFFITH 2004; PURDY; SCHMIDT, 1996), since this pathogen is responsible for up to $70 \%$ of losses in commercial cocoa plantations in northern Brazil, and especially in the State of Rondônia.

M. perniciosa mainly infects meristematic vegetative shoots, inflorescences and fruits resulting in hypertrophied damaged tissues that are unsuitable for cultivation or consumption. Although an integrated disease control management program, including agricultural, chemical, biologic and molecular strategies, is recommended for $M$. perniciosa, a great deal of research in Brazil has focused on cheap and environmentally friendly methods that could be suitable for local farmers. Within this context, the application of bioactive natural products, in the form of a crude plant extract or an essential oil, could be more advantageous than the use of synthetic chemicals since they are likely to be cheaper to produce, less harmful to the environment and less toxic to humans (RAHMAN; HOSSAIN; KANG, 2010; SILVA; BASTOS 2007; STANGARLIN et al., 1999).

Many of the 100 or so species of the genus Ocimum (Lamiaceae) represent valuable sources of essential oils that have been used not only in folk medicine, but also as insect repellents, food flavors and aromatizing agents in fragrances and perfumes. Paula, Gomes-Carneiro, Paumgartten (2003), for example, reported that the oil from Ocimum selloi Benth. was effective against mosquitoes, showed low acute toxicity, posed no mutagenic risk and did not cause irritation to human skin. The main compounds present in the essential oil of $O$. selloi are methyl chavicol (estragole; 1-allyl-4-methoxybenzene), trans-anethole, cis-anethole and caryophyllene (FRANCA et al., 2008; MORAES et al., 2002; VIEIRA; SIMON 2000).

Considering the small number and high cost of agrochemicals available for the eradication of phytopathogens, the emerging signs of resistance towards traditional fungicides, and the need to reduce the environmental impact of synthetic agrochemicals, our research group undertook the task of investigating the in vitro effects of the essential oil from $O$. selloi on the growth of mycelia and the germination of spores of A. alternata, Colletotrichum gloeosporioides (Penz.) Penz. \& Sacc. and M. perniciosa.

\section{MATERIALS AND METHODS}

\section{Plant material}

The leaves and flowers of $O$. selloi were collected from the Lavras county of the Republic of Brazil. The plant was identified on the basis of morphological features and a voucher specimens (number 7474) were deposited in the herbarium of the Department of Biology at Universidade Federal de Lavras (UFLA).

\section{Extraction of the essential oil}

The fresh leaves and inflorescences portions $(100 \mathrm{~g})$ of $O$. selloi were subjected to hydrodistillation for 90 min using a Clevenger type apparatus. The essential oil was dried over anhydrous magnesium sulphate and preserved in a sealed vial at $4^{\circ} \mathrm{C}$ for further analysis.

\section{Gas chromatography-mass spectrometry (GC-MS) analysis}

The GC-MS analysis of the essential oil was performed using a SHIMADZU GC-MS (GC-17A and MS- QP5050A with quadrupole detector) equipped with DB-5 MS fused silica capillary column $(300 \times 0.25 \mathrm{~mm}$ i.d.; $0.25 \mu \mathrm{m}$ film thickness). For GC-MS detection, an electron ionization system with ionization energy of $70 \mathrm{eV}$ was used. The carrier gas helium was used at a constant flow rate of $1.2 \mathrm{ml} \mathrm{min}^{-1}$. Injector and MS transfer line temperature were set at $250{ }^{\circ} \mathrm{C}$ and $280{ }^{\circ} \mathrm{C}$, respectively. The oven temperature was programmed isothermal at $50{ }^{\circ} \mathrm{C}$ for $2 \mathrm{~min}$, increased at $4{ }^{\circ} \mathrm{C} \mathrm{min}^{-1}$ to $200{ }^{\circ} \mathrm{C}$, then raised to $300{ }^{\circ} \mathrm{C}$ at $10{ }^{\circ} \mathrm{C} \mathrm{min}$ me $^{-1}$ and finally held isothermal for $10 \mathrm{~min}$. Diluted samples (20\%, v/v, in dichloromethane) of $0.5 \mu \mathrm{L}$ was injected in the split mode ratio 1:100. 
The relative percentage of the oil constituents was expressed as percentage by peak area normalization.

\section{Identification procedure}

The linear retention indices (RI) for all of the compounds were determined by co-injection of an oil sample with a solution containing the homologous series of $\mathrm{C}_{8}-\mathrm{C}_{32}$ n-alkanes (Sigma, St Louis, MO, USA) and application of the equation of Van den Dool and Kratz (1963). Individual identification of constituents were based by: (a) comparing RI values and key mass spectral features with those published in the literature; (b) comparing individual mass spectra with spectral data from the NIST/EPA/NHI library (National Institute of Standards and Technology 1998); (c) co-injection of an oil sample with authentic standards (ADAMS, 2007).

\section{Fungal pathogens}

The plant pathogenic fungi were obtained from the collection of the Department of Phytopathology at UFLA. Cultures of each fungal species were maintained on potato-dextrose agar (PDA) slants and stored at $4{ }^{\circ} \mathrm{C}$. The fungal species used in the experiment were $A$. alternata (CML 184), C. gloeosporioides (CML 459) and $M$. perniciosa (CEPLAC 1188; CML).

\section{Preparation of spore suspension and standard methyl chavicol}

The spore suspension of $A$. alternata, $C$. gloeosporioides and $M$. perniciosa were obtained from their respective 7 days old cultures, mixed with sterile distilled water to obtain a homogenous spore suspension of $22 \times 10^{4}$ spore $\mathrm{mL}^{-1}$. Essential oil and standard methyl chavicol ( $\geq 98.9 \%$ purity by GC; Riedel-de Haën, Seelze, Germany) were dissolved in $1 \%$ propylene glycol (PG) separately to prepare the stock solutions, which were further diluted to prepare test samples.

\section{Bioassays}

\section{Mycelial growth assay}

In order to evaluate the effects on mycelial growth, essential oil from $O$. selloi and standard methyl chavicol were solubilized separately in $1 \%$ propylene glycol (PG) so as to ease its incorporation into the agar medium. The essential oil and standard methyl chavicol were tested at $125 ; 250 ; 500$; or 1,000 ppm. Two different sets of control ( 0 ppm of essential oil and PG +0 ppm of essential oil) were used. The oil and standard were incorporated to the autoclaved and cooled $\left(40^{\circ} \mathrm{C}\right)$ potato dextrose agar medium (PDA). The medium amended with oil or standard was then poured into sterilized Petri dishes $(9 \mathrm{~cm}$ diameter). A mycelial disc of $7 \mathrm{~mm}$ diameter of the test pathogens taken from a 7 days old culture, using a sterilized cork borer was placed at the centre of the Petri dish containing the medium. The plates were then sealed with parafilm ${ }^{\mathrm{TM}}$ and incubated at chamber room at $25 \pm 1{ }^{\circ} \mathrm{C}$ under a $12 \mathrm{~h}$ photoperiod. The diameter of the growing mycelia was performed every two days, time by which the growth of control would have reached $2 / 3$ of the Petri dish. The plates were used in triplicates for each treatment.

The growth inhibition of oil and standard trails compared to control was calculated by mycelial growth index (MGI), using the following formula: $\mathrm{MGI}=\left(\mathrm{D}_{1} / \mathrm{N}_{1}\right)+$ $\left(D_{2} / N_{2}\right)+\ldots+\left(D_{n} / N_{n}\right)$, where $D_{1}, D_{2}$ and $D_{n}$ represent the diameters of the mycelia at the first, second and last measurements, and $\mathrm{N}_{1}, \mathrm{~N}_{2}$ and $\mathrm{N}_{\mathrm{n}}$ represent the number of days after inoculation.

Additionally, the percentage inhibition of mycelial growth (IMG) was estimated using the equation: $\mathrm{IMG}=[(\mathrm{Dc}-\mathrm{Dt}) \mathrm{x} 100] / \mathrm{Dc}$, in which Dc and Dt represent the diameters of the mycelia in the control and in the treatment, respectively. Bioassays were repeated six times for each of the oil concentrations.

The minimum concentration at which no visible growth was observed was defined as the MIC, which was expressed in ppm and the lethal dose $\left(\mathrm{LD}_{50}\right)$ defined as the concentration that is able to inhibit $50 \%$ of mycelial growth, which was expressed in ppm were determined.

\section{Spore germination assay}

The second bioassay was designed to evaluate the effect of different concentrations of essential oil on the spore germination of the fungal isolates. Glass depression slides (containing three wells each) were placed inside Petri dishes that had been lined with wet filter paper. Each well received an aliquot $(100 \mu \mathrm{L})$ of the essential oil solubilized in $1 \%$ propylene glycol to give a final concentration of $125 ; 250 ; 500$; or 1,000 ppm. Control without essential oil was tested in the same way. Subsequently, a $30 \mu \mathrm{L}$ aliquot of a suspension of spores of A. alternata $\left(22 \times 10^{4}\right.$ spores. $\left.\mathrm{mL}^{-1}\right), C$. gloeosporioides $\left(20 \times 10^{4}\right.$ spores. $\left.\mathrm{mL}^{-1}\right)$ or $M$. perniciosa $\left(24 \times 10^{4}\right.$ spores. $\mathrm{mL}^{-1}$ ) was added to each well and the glass slides were incubated at $25 \pm 1{ }^{\circ} \mathrm{C}$ for $24 \mathrm{~h}$. At the end of the incubation period, each well received few drops of lacto-phenol-cotton blue stain and the slides were observed under the light microscope. All spores exhibiting germ tubes, independent of their length, were considered to be germinating spores. Each treatment involved three repetitions, each one comprising three wells, and 200 spores were counted per well to give a total of 600 spores counted per treatment. The results were expressed as percentage of spore germination.

\section{Statistical analysis}

All experiments were conducted according to a completely randomized design. Mean values were compared using Tukey's test at $\rho \leq 0.05$ and regression analyses. 


\section{RESULTS AND DISCUSSION}

GC/MS analysis of the essential oil from the leaves and inflorescences of $O$. selloi led to the identification of six main components, namely, two phenylpropanoids and four sesquiterpenes, representing $93.86 \%$ and $6.03 \%$ of the total oil respectively. The identified compounds are listed in Table 1 according to their elution order on a DB-5 MS capillary column. The major constituent was methyl chavicol, and this component accounted for more than $93 \%$ of the total oil. The others compounds were methyl eugenol $(0.62 \%), \beta$-caryophyllene $(2.22 \%)$, germacrene-D $(1.33 \%)$, bicyclogermacrene $(1.21 \%)$ and spathulenol (1.27\%).
The essential oil from $O$. selloi was able to inhibit mycelial growth in all three fungal species assayed. The toxic effect was in a dosage response manner, i.e. the higher the concentration of essential oil the greater was the reduction in the growth of mycelia (Fig. 1 and Fig.2). For A. alternata and C. gloeosporioides, maximum IMG values of 45.7 and $13.2 \%$, respectively, were attained when the concentration of essential oil was 1,000 ppm (Table 2). Of more interest, however, was the effect of the essential oil on the mycelial growth of $M$. perniciosa, which was inhibited by $100 \%$ at oil concentrations of 500 and 1,000 ppm (Fig. 2c), and the relative low MIC and $\mathrm{LD}_{50}$ values obtained (Table 2). As shown in Fig. 3, pure methyl

Table 1 - The principal chemical constituents of the essential oil from leaves and inflorescences of Ocimum selloi

\begin{tabular}{lcc}
\hline Compound & $\mathrm{RI}^{\mathrm{a}}$ & Composition $(\%)$ \\
\hline Methyl chavicol & 1198 & 93.24 \\
Methyl eugenol & 1397 & 0.62 \\
B-Caryophyllene & 1418 & 2.22 \\
Germacrene-D & 1480 & 1.33 \\
Bicyclogermacrene & 1494 & 1.21 \\
Spathulenol & 1575 & 1.27 \\
Phenylpropanoids & & 93.86 \\
Sesquiterpenes & & 6.03 \\
TOTAL & & 99.89 \\
\hline
\end{tabular}

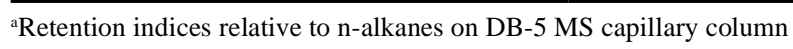

Figure 1 - Effects of different concentrations of essential oil from Ocimum selloi on the mycelial growth index (MGI) of $\diamond$ Alternaria alternata $\left(\mathrm{y}=-0.000001 \mathrm{x}^{2}-0.002150 \mathrm{x}+3.885923 ; \mathrm{R}^{2}=96.18\right), \Delta$ Colletotrichum gloeosporioides $\left(\mathrm{y}=-0.000001 \mathrm{x}^{2}-0.001445 \mathrm{x}+4.437385 ;\right.$ $\left.\mathrm{R}^{2}=99.48\right)$ and $\boldsymbol{\nabla}$ Miliophthora perniciosa $\left(\mathrm{y}=-0.000002 \mathrm{x}^{2}-0.005871 \mathrm{x}+3.496410 ; \mathrm{R}^{2}=70.43\right)$

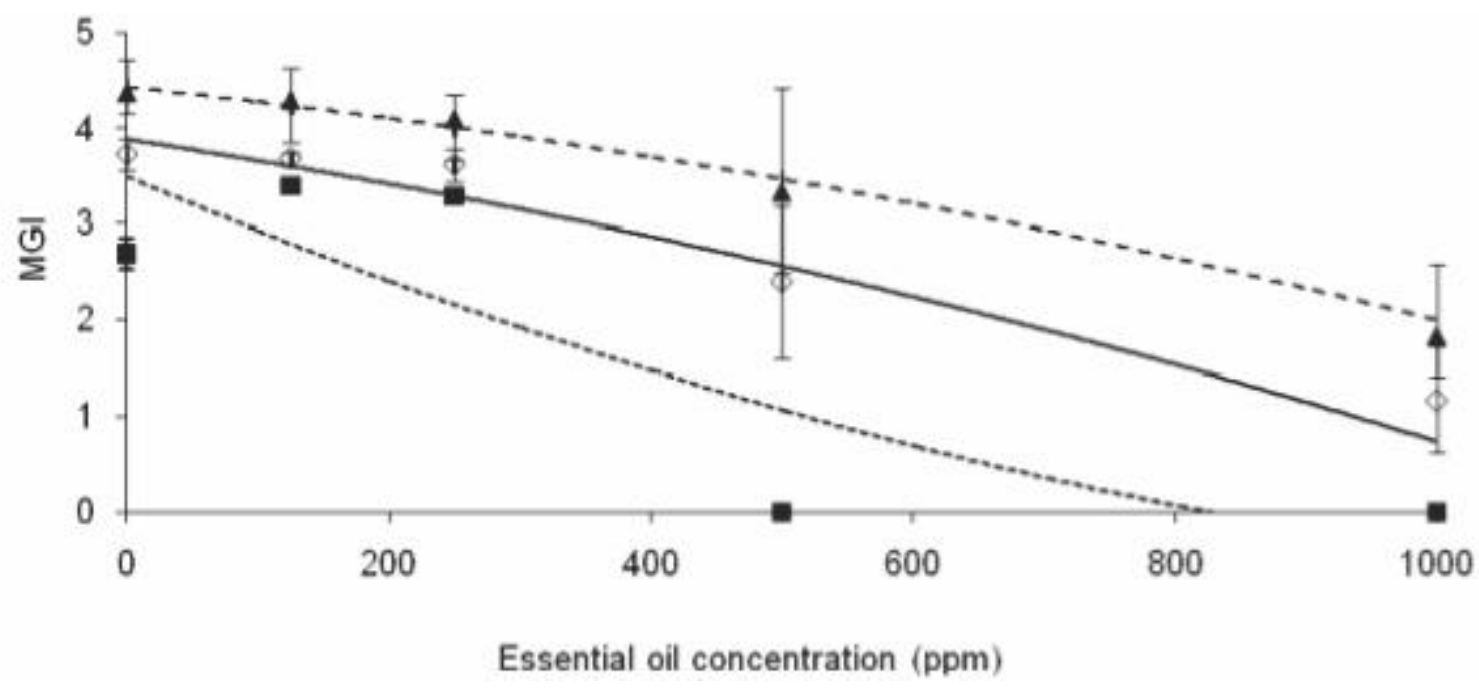


chavicol or estragole also reduced the growth of mycelia of $M$. perniciosa, and complete inhibition of growth was observed at $1,000 \mathrm{ppm}$.

Figure 2 - Effects of different concentrations of essential oil from Ocimum selloi on the growth of mycelia of Alternaria alternata (a), Colletotrichum gloesporioides (b) and Moniliophthora perniciosa (c). Each panel shows - (1) 0 ppm of essential oil (control), (2) PG + 0 ppm of essential oil (control), (3) $125 \mathrm{ppm}$, (4) $250 \mathrm{ppm}$, (5) $500 \mathrm{ppm}$, and (6) $1000 \mathrm{ppm}$. Bar $=5 \mathrm{~cm}$
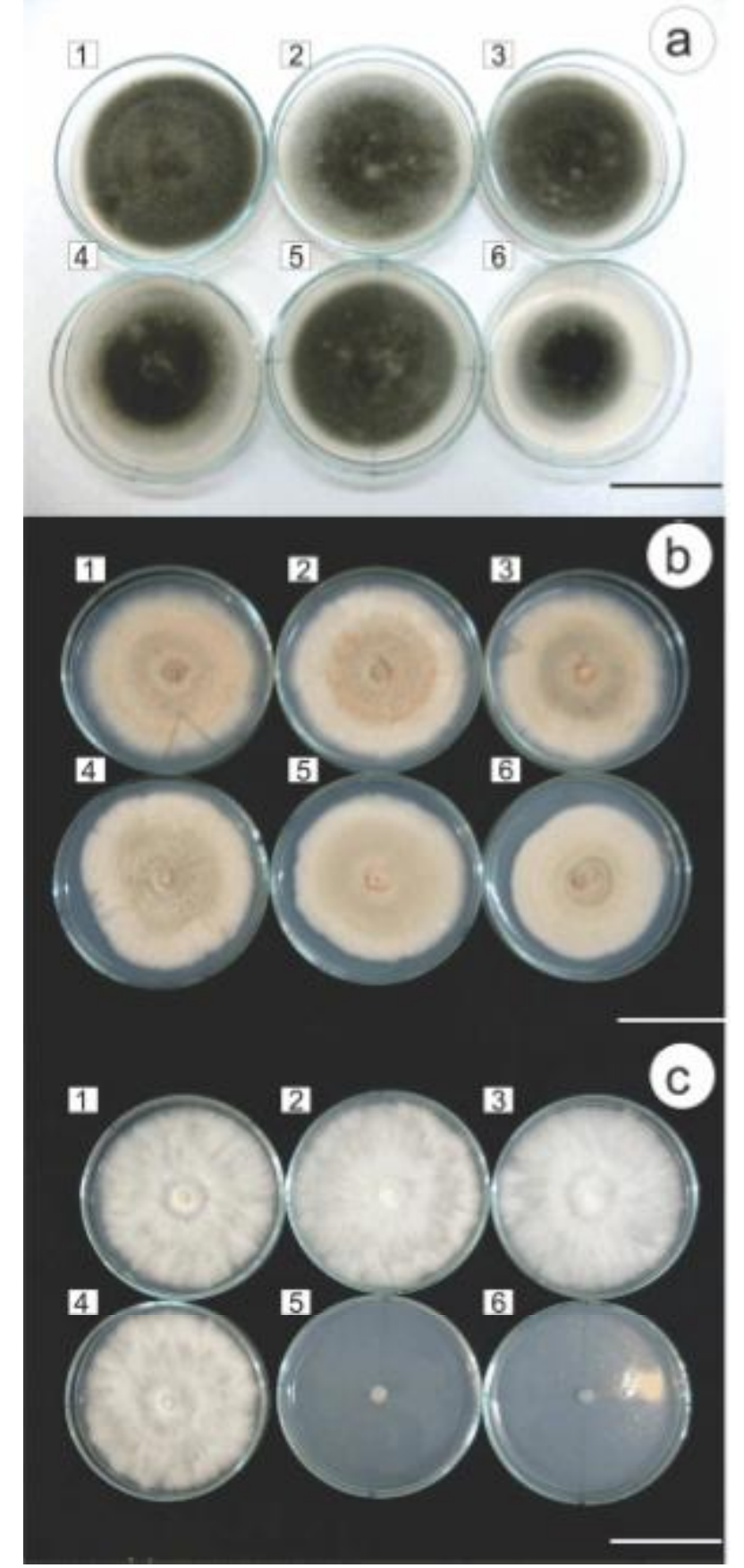

The essential oil from $O$. selloi affected the germination of spores of $C$. gloeosporioides and $M$. perniciosa at all concentrations tested, although the largest reductions in germination (93 and $87 \%$, respectively) were observed at 1,000 ppm (Figure 4). In complete contrast, the germination of $A$. alternata spores was not affected by any of the treatments applied.

The essential oils are promising natural antifungal agents with potential applications in agriculture to control phytopathogenic fungi causing severe destruction of crops. The numerous aromatic and medicinal plants are considered to be non-phytotoxic compounds and potentially effective against plant pathogenic fungi (CAROVIĆ-STANKO et al., 2010).

The hydrodistillation of the leaves and flowers part of $O$. selloi gave light yellowish oil with the major components of the oil having phenylpropanoids and sesquiterpenes. In recent years, several researchers have reported that mono - and sesquiterpenes have

Figure 3 - Effects of different concentrations of methyl chavicol (standard) on the mycelial growth index (MGI) $\left(\mathrm{y}=-5 \mathrm{E}-06 \mathrm{X}^{2}+0.0027 \mathrm{x}+2.5862 ; \mathrm{R}^{2}=99.54 * *\right)$ a) and mycelia growth to Moniliophthora perniciosa (b) - Each panel shows - (1) 0 ppm of methyl chavicol (control), (2) PG +0 ppm of methyl chavicol (control), (3) $125 \mathrm{ppm}$, (4) $250 \mathrm{ppm}$, (5) $500 \mathrm{ppm}$, and (6) $1000 \mathrm{ppm}$ of methyl chavicol. $\mathrm{Bar}=5 \mathrm{~cm}$
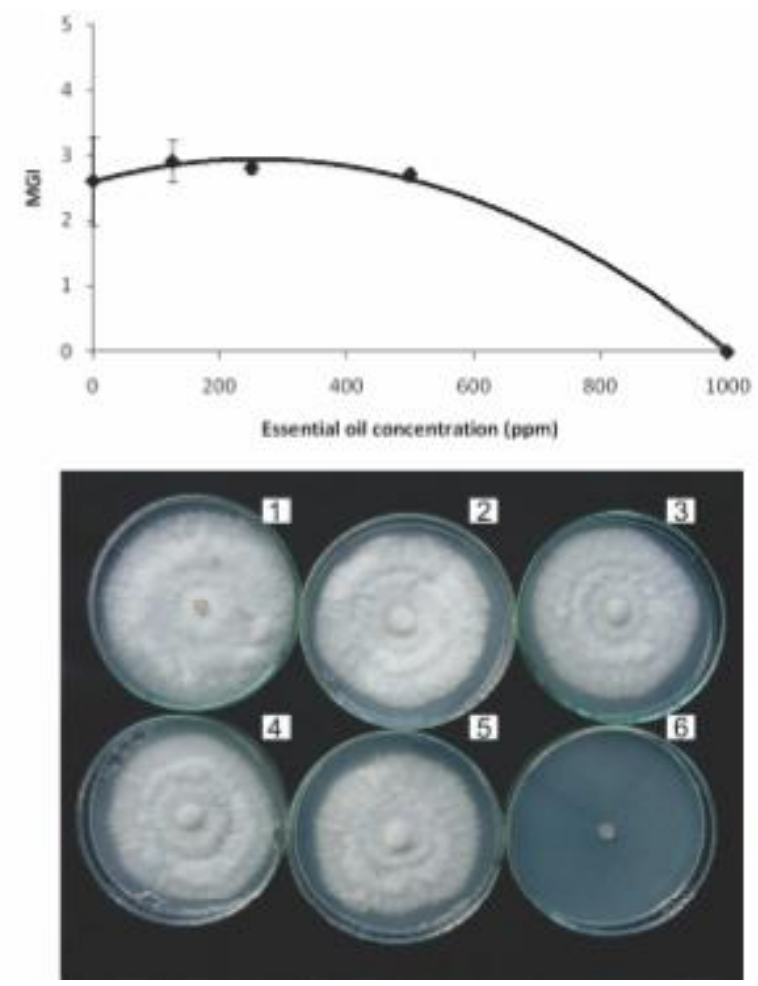
enormous potential to inhibit microbial pathogens (CAROVIĆ-STANKO et al., 2010; RAHMAN; HOSSAIN; KANG, 2010).Also, was reported a significant difference in antifungal activity among functional groups, that phenylpropanoids compounds were more toxic than hydrocarbons (KIM et al., 2008).

The results show that the essential oil of $O$. selloi was able to inhibit the growth of mycelia of the three fungal isolates studied, with the order of sensitivity to the oil being $M$. perniciosa bigger than C. gloeosporioides and A. alternata. Furthermore, the essential oil caused a reduction in the germination of spores of $M$. perniciosa at all concentrations tested, thus indicating a possible application of this natural product in the treatment of infected cacao crops.
Since the major constituent (> 93\%) of the essential oil was methyl chavicol, the fungicidal activity of this phenylpropanoid against $M$. perniciosa was also evaluated. The results revealed that the essential oil and pure methyl chavicol were similarly effective in causing complete inhibition of mycelial growth at a concentration of 1,000 ppm. Previous studies demonstrated that the essential oil from another species of Ocimum, namely $O$. basilicum L., as well as the pure phenylpropanoids methyl chavicol and eugenol, were able to reduce significantly the mycelial growth of the phytopathogenic fungus Botrytis fabae Sardiña(OXENAHM; SVOBODAL; WALTERS, 2005). Additionally, a number of other phenylpropanoids have been reported to exhibit antifungal activity, including apiole (MEEPAGALA et al., 2005; RAZZAGHI-ABYANEH et al., 2007) and the

Table 2 - Percentage inhibition of mycelial growth (IMG) of different concentrations of the essential oil from Ocimum selloi tested against three fungal isolates, minimum inhibitory concentration (MIC) and lethal dose $\left(\mathrm{LD}_{50}\right)$

\begin{tabular}{|c|c|c|c|c|c|c|}
\hline \multirow{3}{*}{ Fungal strains } & \multicolumn{4}{|c|}{$\operatorname{IMG}(\%)$} & \multirow{3}{*}{ MIC (ppm) } & \multirow{3}{*}{$\mathrm{LD}_{50}(\mathrm{ppm})$} \\
\hline & \multicolumn{4}{|c|}{ Essential oil concentration (ppm) } & & \\
\hline & 125 & 250 & 500 & 1,000 & & \\
\hline Alternaria alternata & 0.6 & 1.7 & 19.2 & 45.7 & $>1000$ & 585.17 \\
\hline Colletotrichum gloeosporioides & 0.0 & 4.0 & 3.9 & 13.2 & $>1000$ & 752.23 \\
\hline Moniliophthora perniciosa & 5.4 & 3.2 & 100.0 & 100.0 & $250-500$ & 415.25 \\
\hline
\end{tabular}

Figure 4 - Effects of different concentrations of essential oil from Ocimum selloi on the spore germination from $\diamond$ Alternaria alternata $\left(\mathrm{y}=0.000003 \mathrm{x}^{2}-0.005192 \mathrm{x}+100.034615 ; \mathrm{R}^{2}=0.87\right), \Delta$ Colletotrichum gloeosporioides $\left(\mathrm{y}=0.000073 \mathrm{x}^{2}-0.166687 \mathrm{x}+100.226923 ;\right.$ $\left.\mathrm{R}^{2}=0.99\right)$ and Moniliophthora perniciosa $\left(\mathrm{y}=0.000087 \mathrm{x}^{2}-0.151606 \mathrm{x}+75.846154 ; \mathrm{R}^{2}=0.99\right)$

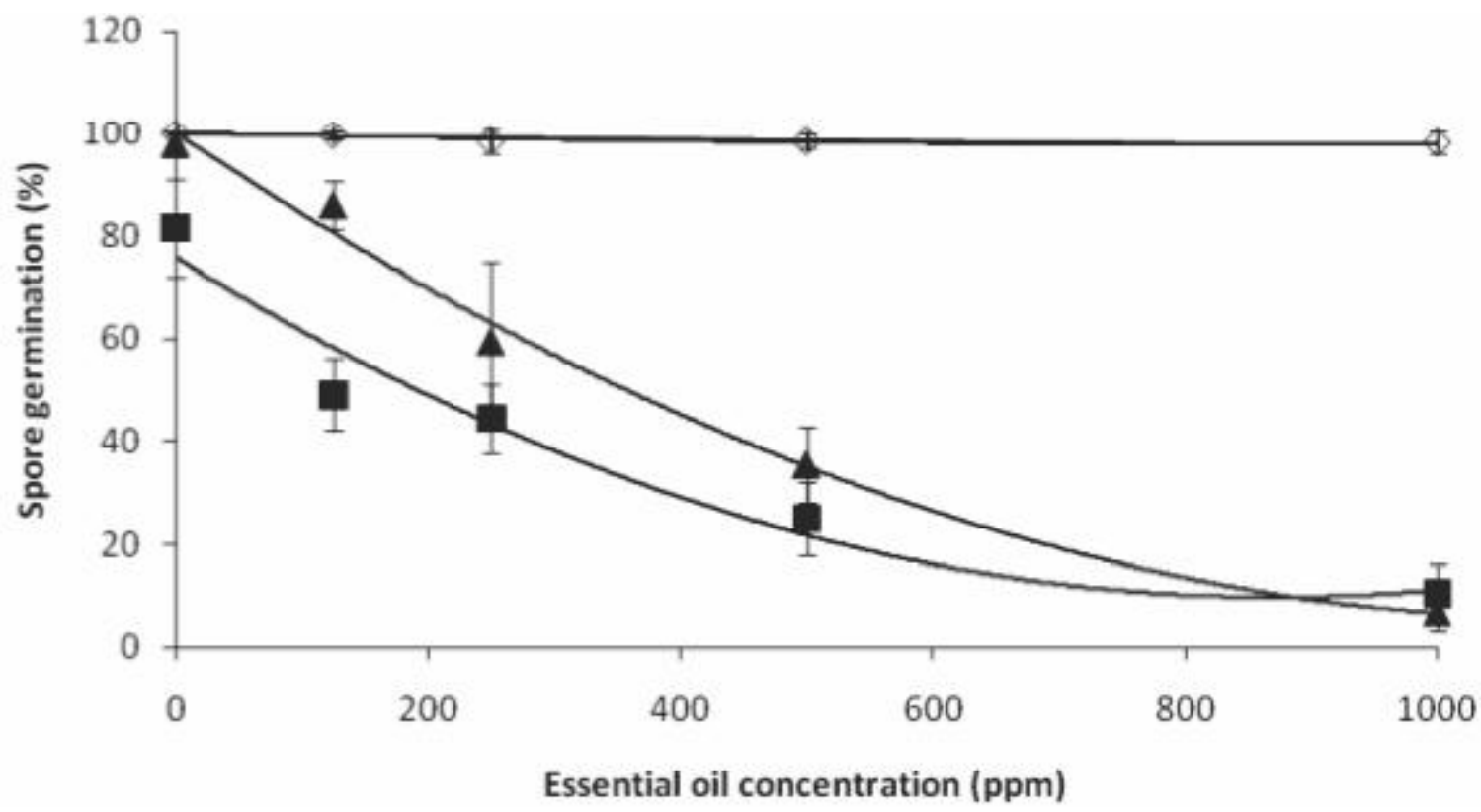


related nothoapiole (LAOUER et al., 2009). In this study, the essential oil showed a remarkable anti-fungal activity against M. perniciosa, which could be attributed to the presence of phenylpropanoids mainly methyl chavicol. This was further supported by our findings, when was used standard methyl chavicol at 1,000 ppm. Although, essential oil at $500 \mathrm{ppm}$ had efficient inhibition effect against M. perniciosa, but the standard at $500 \mathrm{ppm}$ had not effect. It is possible that the minor components might be involved in some type of synergism with the other active compounds. Volatile compounds, such as $\beta$-caryophyllene, spathulenol (RAHMAN; HOSSAIN; KANG, 2010), methyl eugenol (KIM et al., 2008) have been claimed to contain the strong antifungal properties.

Various studies have shown that the essential oils from many aromatic or medicinal plants are active against a range of phytopathogenic fungi. Thus oils from Pimenta racemosa (Mill.) J.W.Moore and Thymus vulgaris L. were able to inhibit completely the growth of the phytopathogenic fungi Phytophthora cactorum (Lebert \& Cohn) J. Schröt. and Cryphonectria parasitica (Murrill) M.E. Barr (KIM et al., 2008), whilst the essential oil from Aloysia gratissima (Gillies \& Hook.) Tronc. was active against $C$. gloeosporioides and Fusarium oxysporum Schltdl. in a dosedependent fashion (CARDOSO, 2005). Treatment of Botrytis cinerea Pers., F. oxysporum and Bipolaris sorokiniana (Sacc.) Shoemaker with essential oil derived from Eucalyptus spp. at a concentration of $500 \mathrm{ppm}$ resulted in a significant reduction of mycelia growth (SALGADO et al., 2003).

With regard to $M$. perniciosa, inhibition of mycelia growth and spore germination by the essential oils and leaf extracts from a number of species of Piper has been described (SILVA; BASTOS, 2007). Thus, the essential oil from $P$. aduncum L. completely inhibited mycelia growth and spore germination in the phytopathogenic fungus when applied at 50 and $100 \mathrm{ppm}$, respectively, whilst oils from $P$. dilatatum Rich., P. callosum Opiz and P. marginatum var. anisatum C.DC. inhibited $M$. perniciosa spore germination at concentrations of 400, 400 and 500 ppm, respectively (SILVA; BASTOS, 2007). Additionally, the essential oils $P$. callosum, $P$. marginatum var. anisatum and $P$. enckea C.DC. exhibited antifungal activities against $M$. perniciosa, Phytophthora palmivora (E.J. Butler) E.J. Butler and $P$. capsici Leonian, all of which attack cacao plants (SILVA; BASTOS, 2007). The present study, however, reports for the first time the antifungal activity of an individual component of an essential oil, namely, pure methyl chavicol against $M$. perniciosa. Although the present findings suggest a possible application of this natural product in the treatment of infected cacao crops, further in vivo studies are required in order to confirm the efficacy of this natural fungicide and to determine its safety. Kim et al. (2008) reported there was a significant difference in antifungal activities among phenylpropanoids, that the position of the double bond of the prophenyl group is also important for antifungal activity.

\section{CONCLUSIONS}

1. The essential oil from $O$. selloi, when applied at a concentration of $1,000 \mathrm{ppm}$, is able to inhibit mycelia growth $(100 \%)$ and spore germination (87\%) of M. perniciosa;

2. The antifungal activity is attributed to the major constituent methyl chavicol, which showed activity at 1,000 ppm similar to that of the essential oil.

3. The essential oil from $O$. selloi was more effective to inhibit mycelia growth and spore germination of $M$. perniciosa that $C$. gloesporioides and A. alternata.

\section{ACKNOWLEDGMENTS}

The authors wish to thank the Conselho Nacional de Desenvolvimento Científico e Tecnológico (CNPq) for fellowships awarded to two of us (JEBPP and PBA), and the Fundação de Amparo à Pesquisa de Minas Gerais (FAPEMIG) and the Coordenação de Aperfeiçoamento de Pessoal de Nível Superior (CAPES) for financial support for the study.

\section{REFERENCES}

ADAMS, R. P. Identification of essential oil components by gas chromatography/mass spectrometry. 4. ed. Illinois: Allured, 2007. 804 p.

CARDOSO, J. C. W. Níveis de luz e homeopatia sobre caracteres morfofisiológicos e óleo essencial e atividade fungitóxica do óleo essencial de Aloysia gratissima (Gilles \& Hook.) Tronc. 2005. 100 p. Dissertação (Mestrado) Universidade Federal de Lavras, Lavras, 2005.

CAROVIĆ-STANKO, K. et al. Composition and antibacterial activities of essential oils of seven Ocimum taxa. Food Chemistry, v. 119, n. 1, p. 196-201, 2010.

CARVALHO, R. R. C. et al. In vitro activity of essential oils of Lippia sidoides and Lippia gracilis and their major chemical components against Thielaviopsis paradoxa, causal agent of stem bleeding in coconut palms. Química Nova, v. 36, n. 2, p. 241-244, 2013.

FRANCA, C. S. et al. Analgesic and antidiarrheal properties of Ocimum selloi essential oil in mice. Fitoterapia, v. 79, n. 7-8, p. 569-573, 2008.

GRIFFITH, G. W. Witches' brooms and frosty pods: threats to world cacao production. The Biologist, v. 51, n. 2, p. 71-75, 2004.

JANSSEN, A. M.; SCHEFFER, J. J.; BAERHEIM-SVENDSEN, A. Antimicrobial activities of essential oils. Pharmacy World \& Science, v. 9, p. 193-197, 1987.

KIM, J. et al. Fumigant antifungal activity of plant essential oils and components from West Indian bay (Pimenta racemosa) and thyme (Thymus vulgaris) oils against two phytopathogenic fungi. Flavour Fragrance Journal, v. 23, n. 4, p. 272-277, 2008. 
LAOUER, H. et al. An antibacterial and antifungal phenylpropanoid from Carum montanum (Coss. et Dur.) Benth. et Hook. Phytotherapy Research, v. 23, p. 1726-1730, 2009.

MEEPAGALA, K. M. et al. Phytotoxic and antifungal compounds from two Apiaceae species, Lomatium californicum and Ligusticum hultenii, rich sources of Z-ligustilide and apiol, respectively. Journal of Chemical Ecology, v. 31, n. 7, p. 1567-1578, 2005.

MORAES, L. A. S. et al. Phytochemical characterization of essential oil from Ocimum selloi. Anais da Academia Brasileira de Ciências, v. 74, n. 1, p. 183-186, 2002.

NATIONAL INSTITUTE OF STANDARDS AND TECHNOLOGY. PC version of the NIST/EPA/NIH mass spectral database. Gaithersburg: NIST, 1998.

OXENAHM, S. K.; SVOBODAL, K. P.; WALTERS, D. R. Antifungal activity of the essential oil of basil (Ocimum basilicum). Journal of Phytopathology, v. 153, n. 3, p. 174-180, 2005.

PAULA, J. P.; GOMES-CARNEIRO, M. R.; PAUMGARTTEN, F. J. R. Chemical composition, toxicity and mosquito repellency of Ocimum selloi oil. Journal of Ethnopharmacology, v. 88, n. 2-3, p. 253-260, 2003.

PURDY, L. H.; SCHMIDT, R. A. Status of cacao witches' broom: biology, epidemiology, and management. Annual Review of Phytopathology, v. 34, p. 573-594, 1996.

RAHMAN, A.; HOSSAIN, M. A.; KANG, S. C. Control of phytopathogenic fungi by the essential oil and methanolic extracts of Erigeron ramosus (Walt.) B.S.P. European Journal of Plant Pathology, v. 128, p. 211-219, Oct. 2010.

RAZZAGHI-ABYANEH, M. et al. Dillapiol and apiol as specific inhibitors of the biosynthesis of aflatoxin G1 in Aspergillus parasiticus. Bioscience, Biotechnology, and Biochemistry, v. 71, n. 9, p. 2329-2332, 2007.
SALGADO, A. P. S. P. et al. Avaliação da atividade fungitóxica de óleos essenciais de folhas de Eucalyptus sobre Fusarium oxysporum, Botrytis cinerea e Bipolaris sorokiniana. Ciência e Agrotecnologia, v. 27, n. 2, p. 249-254, Mar./Apr. 2003.

SILVA, A. C. et al. Essential oils for preventative treatment and control of Asian soybean rust. European Journal of Plant Pathology, v. 134, n. 4, p. 865-871, 2012 a.

SILVA, A. C. et al. Effectiveness of essential oils in the treatment of Colletotrichum truncatum-infected soybean seeds. Tropical Plant Pathology, v. 37, n. 5, p. 305-313, 2012 b.

SILVA, D. M. H.; BASTOS, C. N. Atividade antifúngica de óleos essenciais de espécies de Piper sobre Crinipellis perniciosa, Phytophthora palmivora e Phytophthora capsici. Fitopatologia Brasileira, v. 32, n. 2, p. 143-145, Mar./Apr.? 2007.

SOUZA JÚNIOR, I. T.; SALES, N. L. P.; MARTINS, E. R. Efeito fungitóxico de óleos essenciais sobre Colletotrichum gloeosporioides, isolado do maracujazeiro amarelo. Biotemas, v. 22, n. 3, p. 77-83, 2009.

STANGARLIN, J. R. et al. Plantas medicinais e controle alternativo de fitopatógenos. Biotecnologia Ciência e Desenvolvimento, v. 11, p. 16-21, 1999.

VAN DEN DOOL, H.; KRATZ, P. D. A generalization of the retention index system including linear temperature programmed gas-liquid partition chromatography. Journal Chromatography, v. 11, p. 463-471, 1963.

VIEIRA, R. F.; SIMON, J. E. Chemical characterization of basil (.) Ocimum spp found in the markets and used in traditional medicine in Brazil. Economic Botany, v.54, n.2, p.207-216, 2000

VIGO-SCHULTZ, S. C. et al. Avaliação da eficácia da tintura etanólica de guaco (Mikania glomerata) no controle da podridão negra Xanthomonas campestris pv. campestris) em couve-flor. Semina: Ciências Agrárias, v. 27, n. 4, p. 515-524, 2006. 